\title{
NATO RESILIANCE, DETER AND PROFESIONAL MILITARY EDUCATION
}

\author{
Neno Hristov Hristov \\ Colonel Associate Professor, Ph.D., D. Sc. (National Security) \\ Military Academy Sofia, Bulgaria, email: neno.hristov@gmail.com
}

\begin{abstract}
Our professional military education still lags in the attention it gives to contemporary deterrence problems. We try to provide a comprehensive framework for officer education across the strategic, operational, and tactical domains but curiously fails to highlight the need to teach deterrence in the professional military education classrooms. In this respect, we have to prepare our students for deterrence and escalation issues. It is critical to adapt their core curricula to include vital content on deterrence, escalation, cross-domain conflict, and crisis management under the nuclear shadow. Deterrence is not completely neglected in our core curricula, same individual academic or research faculty offer electives, even first-rate elective classes but still for a small number of students.
\end{abstract}

Keywords: education, NATO, national military and educational system.

\section{INTRODUCTION}

Higher military training institutions in Bulgaria have begun to introduce up-to-date approaches to the training of specialists, ensuring that the graduate's skill level is as close as possible to force requirements. One of the main task of Bulgarian professional military education system is to overcome the psychological barrier between civilian in GO and NGO and military staff in all command levels, and establishing friendly relations between higher military education institutions and civilian staff.

\section{DETER AND PROFESIONAL MILITARY EDUCATION}

The curriculum Bulgarian professional military education system is based on the Professional Body of Knowledge, which consist core, supporting and specialized bodies of knowledge. Core Knowledge is the unique, theory-based knowledge at the core of the Bulgarian Profession of Arms. "It includes, "tactics and tactical doctrine, the broad and deep discipline of operational art, the operational, technological, logistical and social dimensions of strategy, civil-military relations, command and leadership theory and practice, and the theory and practice of military professionalism."

"Supporting Knowledge includes everything necessary to support a large organization whose primary function is to operate effectively across the spectrum of conflict, up to and including combat. This expertise is normally organized through highly differentiated systems of support, such as the communications, logistics, human resources, legal, and professional development systems. „Also in this category is a very wide range of expertise encompassed in such disciplines as Bulgarian history, military history, political science, psychology, sociology, anthropology, and management theory, among others." 
Specialized Knowledge is particular to groups whose expertise is not specific to the military such as doctors, lawyers, clergy, engineers and psychologists. The Professional Body of Knowledge is described in a range of BAF documents and publications ranging from strategy statements to doctrine.

Comprehensive Knowledge is related to the HATO comprehensive approach and the need military and civilian to work together. This knowledge help to authorities have better and common understand of security environment and defence challenges related to NATO resilience and deter approach.

As a higher education institution, the National Defense College GS Rakovski appreciate the complexities and difficulties of adequately "teaching" resilience. The principle of resilience is firmly anchored in Article 3 of the Alliance's founding treaty: "In order more effectively to achieve the objectives of this Treaty, the Parties, separately and jointly, by means of continuous and effective self-help and mutual aid, will maintain and develop their individual and collective capacity to resist armed attack." This means that, if it is considered as a topical issue, we seriously addressed it to the educational programs. The new training programs has resulted in the higher military education system moving gradually from a traditional, classical and static educational process to a dynamic system of rapid changes to training standards, programs, and forms and methods based on ongoing analysis of how forces have been used in deter operations and lessons from local wars and modern-day conflicts. This programs includes conferences, seminars, roundtables, instructional and methodological classes, demonstrations and participation of teaching staff in NATO responce operations. We have committed to providing our armed forces with sufficient capabilities that respond to modern challenges to resilience of defense as:

- build resilience against cyber defense;

- build resilience against hybrid threat;

- build resilience against terrorist attacks;

- capacity to resist any form of armed attack;

- resilience to provide own security;

- resilience in a changed security environment;

- resilience against political and economic pressure;

- resilience in stepping up cooperation with the EU;

- resilience in working with partner countries.

In our college, a master degree program provides knowledge about the fight against radicalization and terrorism. We have a number of programs and courses designed to build capabilities for resilience of cyber defence, hybrid threat, terrorist attacks, any form of armed attack, providing own security, answer to the changes in security environment, political and economic pressure.

Our professional military education still lags in the attention it gives to contemporary deterrence problems. We try to provide a comprehensive framework for officer education across the strategic, operational, and tactical domains but curiously fails to highlight the need to teach deterrence in the professional military education classrooms. In this respect, we have to prepare our students for deterrence and escalation issues. It is critical to adapt their core curricula to include vital content on deterrence, escalation, cross-domain conflict, and crisis management under the nuclear shadow. Deterrence is not completely neglected in our core curricula, same individual academic or research faculty offer electives, even first-rate elective classes but still for a small number of students.

Our main goal is to develop a Master degree programs and courses that will enable officers and civilians to become fully acquainted with the theory of a comprehensive approach so that they can practically use strategic deterrence and security.

Professional military education contribute to national and NATO efforts to build unique capabilities for maintaining peace, security and stability of international community, in full coordination with other actors. NATO recognize that only military means are not enough to meet the many complex challenges to our security. The effective implementation of a comprehensive approach to crises requires nations, international organizations and non-governmental organizations to contribute in a concerted effort. As additional knowledge to the comprehensive approach professional military education have to cover, also the following identified as critical seven areas (systems or capabilities):

- Continuity of Government; 
- Resilient Energy Supplies;

- Resilient Civil Communications Services;

- Resilient Food and Water Supplies;

- Ability to Deal with Large Scale Population Movements;

- Ability to Deal with Mass Casualties;

- Resilient Civilian Transportation Systems.

Because resilience is seen first and foremost as a domestic task, professional military education should provide abilities to answer to the six main tasks, spanning from identification of critical vulnerabilities to implementation of the mandatory measures and planning for uncertainty:

- Invest time and human resources in assessing national vulnerabilities - for instance, infrastructure and different types of networks. One of the best examples is the focus on energy infrastructure and cyber networks;

- Develop a coherent policy across the board, with an overall focus on "shaping, planning and managing resilience in a coherent and coordinated way". This has to take into account two dimensions. First, the physical domain - the "hardware stuff" - will harness and improve redundancy and robustness of existing infrastructure and networks. The second dimension, which is by nature broader and far more complex to deal with, aims at developing resilience among our own population. This deals above all with education and information, at every level and in all possible dimensions;

- Modify, change or make the legislation evolve in certain domains, especially in granting national governments and administrations greater flexibility to deal with the notion of crisis; and avoid the black-andwhite separation between what can be done in peacetime and wartime;

- Improve the ability to partner with the civilian and/or private sector. This means that every actor must be aware of what is critically needed, and that there must be channels of communication among those concerned, without putting any constraint on the freedom of entrepreneurship;

- Review, modernize, update and learn planning documents, in order to take stock of new threats and start exercising them accordingly with a view to showing our resilience;

- Teach haw to connect and link up with other organizations so as to leverage different capabilities, especially in the economic and social domain. Of course, for NATO, this means further developing its links and relations with the European Union.

The last but not list task of professional military education is to increase the civil preparedness in crisis management and teach them how to:

- assured continuity of government and critical government services: for instance the ability to make decisions, communicate them and enforce them in a crisis;

- to increase the resilience of energy supplies: back-up plans and power grids, internally and across borders;

- to deal effectively with uncontrolled movement of people, and to de-conflict these movements from NATO's military deployments;

Resilient food and water resources: ensuring these supplies are safe from disruption or sabotage; Civilmilitary readiness

- to deal with mass casualties: ensuring that civilian health systems can cope and that sufficient medical supplies are stocked and secure;

- to increase the resilience of civil communications systems: ensuring that telecoms and cyber networks function even under crisis conditions, with sufficient back-up capacity; and

- to increase the resilience of transport systems: ensuring that NATO forces can move across Alliance territory rapidly and that civilian services can rely on transportation networks, even in a crisis.

\section{CONCLUSION}

The comprehensive nature of the types and methods of training, in cooperation with experts in various specializations, NGO and GO, forms the basis of professional comprehensive training, along with the broad 
involvement of students and teaching staff. The implementation of the conceptual principles to further development of military education must guarantee the transition to a new type of comprehensive and innovative military education, one that will increase the professional, intellectual, scientific, cultural, spiritual and moral potential of military and civilian specialists (Kanev, Terziev, 2017a, 413-423; Kanev, Terziev, 2017b, 595-606; Sotirov, Terziev, 2015a, 197-207; Sotirov, Terziev, 2015b, p25; Sotirov, Terziev, Minev, Ivanov, 2016c, 15-21; Terziev, 2017a; Terziev , 2016b, 84-90; Terziev, 2017c, p252; Terziev, 2017d, pp.2228; Terziev, Vezieva, Arabska, 2016e, 106-121; Terziev, Manoliv, 2016f, pp.15-20; Terziev, Minev, Sotirov, Ivanov, 2016g, 272-292; Terziev, Kanev, 2017h, pp.733-742; Terziev, Madanski, 2017i, pp.8-16; Terziev, Madanski, 2017j, pp.17-28; Terziev, Madanski, 2017k, pp.28-36; Terziev, Madanski, 2017l, pp.610-625; Terziev, Madanski, 2017m, pp.575-594; Terziev, Madanski, Kanev, 2017n, pp.396-415; Terziev, Madanski, Kanev 2017o, pp.1331-1346; Terziev, Madanski, Kanev 2017p, pp.1355-1372; Terziev, Madanski, Kanev 2017q, pp.1380-1393).

\section{REFERENCE LIST}

Kanev, D.,Terziev. V. (2017a). Behavioral economics: development, condition and perspectives, IJASOSInternational E-Journal of Advances in Social Sciences, Vol. III, Issue 8, e-ISSN: 2411-183X.

Kanev, D.,Terziev. V. (2017b). Behavioral economics: development, condition and perspectives. Proceedings of SOCIOINT 2017- 4th International Conference on Education, Social Sciences and Humanities 10-12 July 2017- Dubai, UAE, ISBN: 978-605-82433-1-6.

Sotirov, B., Terziev, V. (2015a). Predizvikatelstva i perspektivi pred obuchenieto po tehnologichni distsiplini, Parva mezhdunarodna nauchna konferentsiya „Predizvikatelstva pred savremennite organizatsii, svarzani s postigane na ustoychivost - znanie i inovatsii v upravlenieto i funktsioniraneto",Plovdiv. ISBN 978-619-7246-04-9 (DVD), ISBN 978-619-7246-06-3 (e-book).

Sotirov, B., Terziev, V. (2015b). Challenges and perspectives to the training in technological subjects, Book of Abstracts: First International Scientific Conference „Sustainability Challenges in Modern Organizations - Knowledge \& Innovation in Management \& Operation", ISBN 978-619-7246-03-2 (DVD), ISBN 978-619-7246-05-6 (e-book).

Sotirov, B., Terziev. V., Minev, R., Ivanov. K. (2016c). Rusenskiyat universitet „Angel Kanchev“ i perspektivite na inovatsionnoto razvitie na Severna Balgariya. VII international scientific and applicative conference KNOWLEDGE WITHOUT BORDERS, 8 - 10 april 2016 g., Bansko, Balgariya. Knowledge International Journal Scientific papers Vol. 12.1, ISSN 1857-92.

Terziev. V. (2017a). National security of the republic of Bulgaria, The Chinese Journal of International Politics, №1(10), ISSN 1750-8916. Source Normalized Impact per Paper (SNIP): 1.105, SCImago Journalk Rank (SJR): 0.815, Impackt factor: 1.594.

Terziev. V. (2016b). Human resource management systems in security and defense: social policies for social activities. -XXXII Mezhdunarodnaya nauchno-prakticheskaya konferentsiya, Evraziyskiy soyuz uchenayh (ESU), Ezhemesyachnayy nauchnayy zhurnal № 12 (33)/ 2016 Chasty 1, Moskva 30.12.2016g., ISSN 2411-6467.

Terziev. V. (2017c). Entry Opportunities in the Bulgarian Military - Educational System and Ensuring of Civil Rights. 3rd Central and Eastern European LUMEN International Scientific Conference New Approaches in Social and Humanistic Sciences 8-10 June 2017 | Chisinau, Republic of Moldova, ISBN: 978-973-166-461-3.

Terziev. V. (2017d). National security of the republic of Bulgaria. -International Journal of Management and Applied Science, Volume-3, Issue-4, ISSN: 2394-7926.

Terziev, V., Vezieva. V., Arabska, A. (2016e). Balgarskite universiteti i vazmozhnostite na Operativna programa „Nauka i obrazovanie za inteligenten rastezh". Mezhdunarodna nauchna konferentsiya „Obrazovanie, nauka, ikonomika i tehnologii“ 23-24 yuni 2016 g. Akademichno spisanie „Upravlenie i obrazovanie“" Tom XII(1) 2016, ISSN 1312-6121.

Terziev, V., Manolov.D. (2016f). Sazdavane na dobra organizatsionna sreda za nauchnoizsledovatelska deynost (Creation of good organizational environment for scientific research activity), Aktual'nyye problemy globalizatsii, Saloniki, Gretsiya (Actual problems of globalization, August 29, 2016, 
Thessaloniki, Greece), Scientific journal „ECONOMICS AND FINANCE“, Actual problems of globalization - Collection of scientific articles, ISBN 978-617-7214-34-1.

Terziev, V., Minev, R., Sotirov, B., Ivanov, K. (2016g). Vazmozhnosti za izgrazhdane na tsentar za kompetentnost $v$ Severen tsentralen rayon na Republika Balgariya. Godishna universitetska nauchna konferentsiya, 20-21 oktomvri 2016 g. NVU „Vasil Levski“ - Veliko Tarnovo. Sbornik dokladi tom 2, Nauchni napravleniya „Prirodomatematicheski nauki” i „Tehnicheski nauki”, ISSN 1314-1937.

Terziev. V., Kanev, D. (2017h). Education and Behavioural Failures, Proceedings of ADVED 2017- 3rd International Conference on Advances in Education and Social Sciences 9-11 October 2017- Istanbul, Turkey, ISBN: 978-605-82433-0-9.

Terziev, V, Madanski, V. (2017i). Entry opportunities in the bulgarian military - educational system (Vazmozhnosti za vklyuchvane vav voennoobrazovatelnata sistema na Balgariya), Topical questions of contemporary science, United States of America 2017, ISBN 978-0-9988732-1-3.

Terziev, V, Madanski, V. (2017j). Development of military education system in Bulgaria (razvitie na voennoobrazovatelnata sistema $v$ Balgariya). Topical questions of contemporary science, United States of America 2017, ISBN 978-0-9988732-1-3.

Terziev, V, Madanski, V. (2017k). Guidelines for development of military education system in Bulgaria (Nasoki za razvitie na voennoobrazovatelnata sistema na Balgariya). Topical questions of contemporary science, United States of America 2017, ISBN 978-0-9988732-1-3.

Terziev, V, Madanski, V. (2017I). Guidelines for development of military education system in Bulgaria. Proceedings of the VII International Academic Congress "Fundamental and Applied Studies in EU and CIS Countries" (United Kingdom, Cambridge, England, 26-28 February 2017). Volume VII. Cambridge University Press, ISBN: 978-0-875-83597-4.

Terziev, V, Madanski, V., Kanev, D. (2017m). Entry opportunities in the bulgarian military-educational system and ensuring of civil rights. Proceedings of SOCIOINT 2017- 4th International Conference on Education, Social Sciences and Humanities 10-12 July 2017- Dubai, UAE, ISBN: 978-605-82433-1-6.

Terziev, V, Madanski, V., Kanev, D. (2017n). Entry opportunities in the bulgarian military-educational system and ensuring of civil rights, IJAEDU- International E-Journal of Advances in Education, Vol. 3, Issue 8, August 2017, e-ISSN:2411-1821.

Terziev, V, Madanski, V., Kanev, D.(20170). Entry opportunities in the Bulgarian military-educational system, Sport, Education and Society, Issue 8 (2), Volume 22. Taylor \& Francis, Print ISSN: 1357-3322 Online ISSN: $1470-1243$.

Terziev, V, Madanski, V., Kanev, D. (2017p). Condition and capabilities of the military-educational system of the Republic of Bulgaria, - Sport, Education and Society, Issue 8 (2), Volume 22. Taylor \& Francis, Print ISSN: 1357-3322 Online ISSN: 1470-1243.

Terziev, V, Madanski, V., Kanev, D. (2017q). Directions for improvement of the military-educational system and its contribution for strengthening national security and the defence of the country, - Sport, Education and Society, Issue 8 (2), Volume 22. Taylor \& Francis, Print ISSN: 1357-3322 Online ISSN: 1470-1243. 